\title{
NATURAL HAZARDS - SOME INTRODUCTORY THOUGHTS
}

DOI: $10.3986 /$ AGS53300

UDC: $911.2: 504.4$

COBISS: 1.03

Blaž Komac, Ph. D.

Anton Melik Geographical Institute

Research Centre of the Slovenian Academy of Sciences and Arts

Gosposka ulica 13, SI - 1000 Ljubljana, Slovenia

E-mail: blaz.komac@zrc-sazu.si

Matija Zorn, Ph. D.

Anton Melik Geographical Institute

Research Centre of the Slovenian Academy of Sciences and Arts

Gosposka ulica 13, SI - 1000 Ljubljana, Slovenia

E-mail:matija.zorn@zrc-sazu.si

\section{Milivoj B. Gavrilov, Ph. D.}

Department of Geography, Tourism and Hotel Management

Faculty of Sciences, University of Novi Sad

Trg Dositeja Obradovića 3, 21000 Novi Sad, Serbia

E-mail: milivoj.gavrilov@yahoo.com

Slobodan B. Marković, Ph. D.

Department of Geography, Tourism and Hotel Management Faculty of Sciences, University of Novi Sad

Trg Dositeja Obradovića 3, 21000 Novi Sad, Serbia

E-mail: slobodan.markovic@dgt.uns.ac.rs 


\section{Introduction}

In 2011 we started to publish special issues in Acta geographica Slovenica aiming to bring attention to selected topics we find interesting for our readers. While we published several articles on geotourism (e.g. Hose et al. 2011) in 51-2 issue, we are going to present two topics in 2013 and 2014 - this issue and 54-1 issue bring discussions on natural hazards, and in the issues 53-2 and 54-2 articles on cultural values and sustainable rural development (e.g. Bole, Pipan and Komac 2013).

\section{Natural hazards - some introductory thoughts}

In recently published Encyclopedia of Natural Hazards (Bobrowsky 2013) »natural hazard « is difined as "an unexpected and/or uncontrollable natural event of unusual magnitude that might threaten people" (Bokwa 2013, 711). Many authors tried to define the term as well as the related expression natural disaster as shown by one of the folowig papers (Lukić et al. 2013). The editors of the special issue understand the latter as »natural phenomena and processes in a landscape that affect society to the extent that they cause damage to it « (Zorn and Komac 2011, 9).

The question that often rises today is: Are natural hazards increasing? This may be because of several »mega-disasters « in recent years, e.g. Southeast Asia earthquake and tsunami in 2004, hurricane Katrina in the US in 2005, Haiti earthquake in 2010, Japanese earthquake and tsunami in 2011 or floods in Central Europe in 2002 and 2013, and mass media covering them extensively. But back to the question - Guha-Sapir, Hagitt and Hoyos $(2004,53)$ answer that natural hazards are probably increasing but "not significantly. But the number of people vulnerable and affected is definitely on the increase".

The notion that natural hazard are increasing/are going to increase can also be associated with the future perspectives of climate scenarios, as by 2100 »climate change is expected to cause an increase of $1.1-6.4^{\circ} \mathrm{C}$ in the global average surface air temperature, and a rise of sea level of between 18 and $59 \mathrm{~cm} . "$ These will/may lead to more climate related natural hazards (Alcántara-Ayala 2010, 276).

Good example of vulnerability of modern society to natural hazards is the Japanese earthquake and tsunami in 2011 that was the costliest natural disaster to date with the total damage more than $\$ 210$ billon (Münchner ... 2012) and which is discussed in one of the following articles (Milošević et al. 2013).

After an event we usually look at »The cycle of integrated risk management « (e.g. Schmid 2006, 10) and ask ourselves what went wrong or which part of it was neglected prior to or after the event leading to extensive damage. Part of the answer is hidden in the changing perception of each part of the »risk cycle«. To find this out we conducted a word frequency count of ten different documents (Bernard et al. 2006;

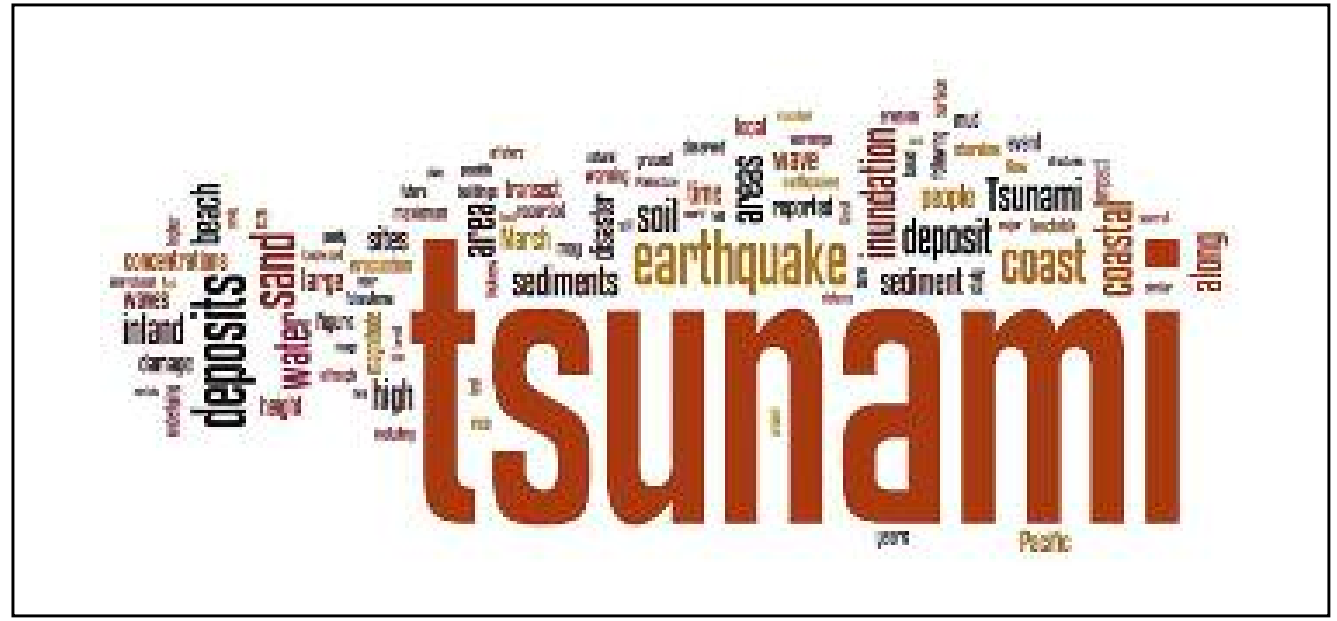

Figure 1: Word cloud of documents related to Japanese earthquake and tsunami in 2011. 


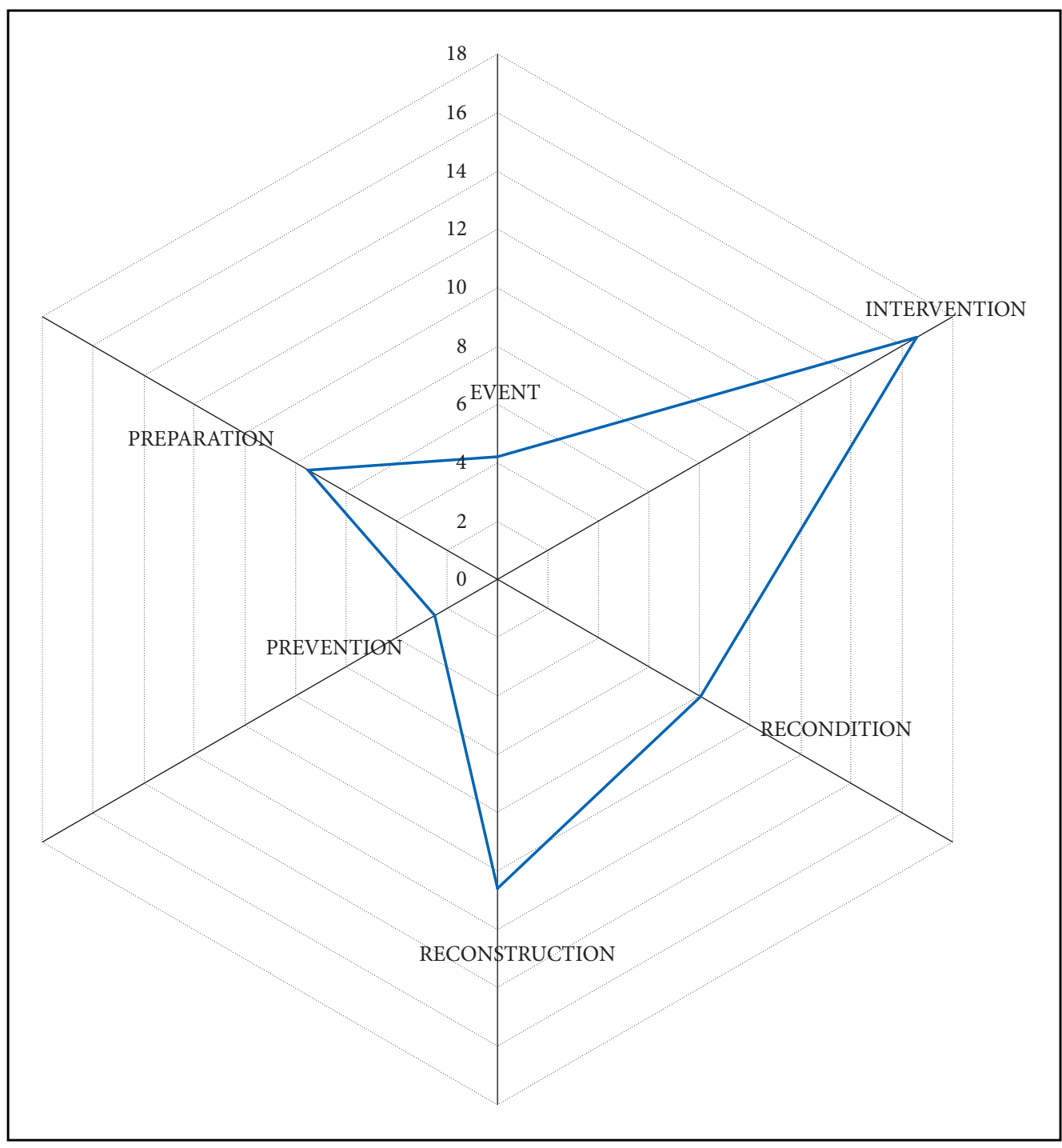

Figure 2: Word count of documents related to Japanese earthquake and tsunami in 2011 with regard to the risk cycle of integrated risk management (in percent).

Mimura et al. 2011; Chagué-Goff et al. 2012; Disasters ... 2012; Nukiwa 2012; Richmond et al. 2012; Tsunami ... 2013) covering the Japanese earthquake and tsunami in 2011 to see on which part of the »risk cycle» focus these documents (Figure 1 and 2).

\section{Articles}

As mentioned above, papers of this special issue are placed in the present issue of Acta geographica Slovenica as well as in the issue 54-1. Together seven paper are going to be presented.

Lukić et al. (2013) present contemporary trends in classification of natural hazards and attempts to harmonize them with some examples from Serbia. 
Gavrilov et al. (2013) discuss the problem of hail suppression in Serbia. The paper critically evaluates decades of hail suppression as the data in the period from 1967 to 2010 show that the hail trend is rising which is in contrary to expectations and claims that hail suppression decreases hail frequency.

Milošević et al. (2013) discuss the Fukushima nuclear disaster and how it affected the changes in nuclear energy policy in the »developed countries « and how this policy stayed mostly unaffected in the »developing countries «.

Marković et al. (2014) present numerical simulation of the complete drying out of the Aral and Caspian Seas and the potential impact that this may have to the climate and environment in the region and globally.

Kovačević-Majkić et al. (2014) present risk education in Serbia as a tool to raise awareness, reduce vulnerability and strengthen the resilience of the population against natural hazards.

Svirčev et al. (2014) propose a concept of ecoremediation as a potential solution for different water quality problems in aquatic ecosystems.

Tošić et al. present a study on landslide susceptibility zonation from Banja Luka Municipality (Bosnia and Herzegovina) where 216 landslides were identified with total surface of $2.9 \mathrm{~km}^{2}$.

\section{Conclusion}

As short analysis of one of the largest natural disasters ever shows the focus of articles which are describing the phenomena from different perspectives (sedimentology, erosion, environment, medicine, preparedness, mitigation and humanitarian aid) is mainly directed to the first phase of the »risk cycle«, e.g. to the intervention phase. Due to large-scale damage the articles were also focused on reconstruction phase. On the other hand, the prevention phase in articles is neglected in our thought and practice (Figure 2).

In our opinion this reflects the modern society with high level of individualization, low level of public participation leading to low level of trust and focus of the society on the "yellow « aspects of natural hazards. Natural hazards are dues perceived as an obstacle to progress that can be overcome using modern technology and not as natural phenomena that occur in natural as well as in urban environment.

The resilience of modern society seems to be lower than usually perceived. Several examples (Kuhlicke et al. 2011) bring our attention to the fact that only long-term activities aiming to understand the nature, its features, effects, and extent of natural processes together with too often neglected social aspects of natural hazards may increase resilience and lower losses in long term. To achieve this the prevention phase should become the first phase of the »risk cycle«.

\section{Acknowledgement}

Presented papers are associated with the »Natural Hazards - lessons from the past, prevention and prediction « meeting, held in Novi Sad, Serbia on May 5, 2012, organized by the Department of Geography, Tourism and Hotel Management, Faculty of Sciences, University of Novi Sad. The objective of the meeting was to bring together researchers from the Southeast European region and to exchange experiences on the topic.

\section{References}

Alcántara-Ayala, I. 2010: Geomorphology and disaster prevention. Geomorphological Hazards and Disaster Prevention. Cambridge.

Bernard, E. N., Mofjeld, H. O., Titov, V., Synolakis, C. E., González, F. I. 2006: Tsunami: scientific frontiers, mitigation, forecasting and policy implications. Philosophical transactions of the Royal Society 364-1845. London. DOI: 10.1098/rsta.2006.1809

Bobrowsky, P. T. (ed.) 2013: Encyclopedia of Natural Hazards. Dordrecht. DOI: 10.1007/978-1-4020-4399-4

Bokwa, A. 2013: Natural hazard. Encyclopedia of Natural Hazards. Dordrecht. DOI: 10.1007/978-1-40204399-4_248 
Bole, D., Pipan, P., Komac, B. 2013: Cultural values and sustainable rural development: A brief introduction. Acta geographica Slovenica 53-2. Ljubljana. DOI: 10.3986/AGS53401

Brussels.

Chagué-Goff, C., Niedzielski, P., Wong H. K. Y., Szczuciñski, W., Sugawara, D., Goff, J. 2011: Environmental impact assessment of the 2011 Tohoku-oki tsunami on the Sendai plain. Sedimentary geology 282. New York. DOI: 10.1016/j.sedgeo.2012.06.002

Disasters: Learning from Japan's tsunami, 2012. Internet: http://www.preventionweb.net/english/professional/news/v.php?id=25574 (5.6.2013)

Gavrilov, M. B., Marković, S. B., Zorn, M., Komac, B., Lukić, T., Milošević, M., Janićević, S. 2013: Is hail suppression useful in Serbia? - General review and new results. Acta geographica Slovenica 53-1. Ljubljana. DOI: 10.3986/AGS53302

Goto, K., Chagué-Goff, C., Goff, J., Jaffe, B. 2012: The future of tsunami research following the 2011 Tohoku-oki event. Sedimentary Geology 282. New York. DOI: 10.1016/j.sedgeo.2012.08.003

Guha-Sapir, D., Hargitt, D., Hoyois, P. 2004: Thirty years of natural disasters 1974-2003: The numbers.

Hose, T. A., Marković, S. B., Komac, B., Zorn, M. Brussels. 2011: Geotourism - a short introduction. Acta geographica Slovenica 51-2. Ljubljana. DOI: 10.3986/AGS51301

Kovačević-Majkić, J., Milošević, M. V., Panić, M., Miljanović, D., Ćalić, J. 2014: Risk education in Serbia. Acta geographica Slovenica 54-1 (in press). Ljubljana. DOI: 10.3986/AGS54305

Kuhlicke, C., Steinführer, A., Begg, A., Bianchizza, C., Bründl, M., Buchecker, M., De Marchi, B., Di Masso Tarditti M., Höppner, C., Komac, B., Lemkow, L., Luther, J., McCarthy, S., Pellizzoni, L., Renn, O., Scolobig, A., Supramaniam, M., Tapsell, S., Wachinger, G., Walker, G. 2011: Perspectives on social capacity building for natural hazards: outlining an emerging field of research and practice in Europe. Environmental Science \& Policy 14-7. Exeter. DOI: 10.1016/j.envsci.2011.05.001

Lukić, T., Gavrilov, M. B., Marković, S. B., Komac, B., Zorn, M., Mladjan, D., Đordjević, J., Milanović, M., Vasiljević, Dj. A., Vujićič, M. D., Kuzmanović, B., Prentović, R. 2013: Classification of the natural disasters between the legislation and application: experience of the Republic of Serbia. Acta geographica Slovenica 53-1. Ljubljana. DOI: 10.3986/AGS53301

Marković S. B., Ruman, A., Gavrilov, M. B., Stevens, T., Zorn, M., Komac, B., Perko, D. 2014: Modelling of the Aral and Caspian Seas drying out influence to climate and environmental changes. Acta geographica Slovenica 54-1 (in press). Ljubljana. DOI: 10.3986/AGS54304

Milošević, Z., Vesković, M., Gavrilov, M. B., Lukić, T., Marković, S. B. 2013: Using natural disasters to instigate radical policy changes - the effect of Fukushima nuclear power plant accident on nuclear energy policies. Acta geographica Slovenica 53-1. Ljubljana. DOI: 10.3986/AGS53303

Mimura, N., Yasuhara, K., Kawagoe, S., Yokoki, H., Kazama. S. 2011: Damage from the Great East Japan Earthquake and Tsunami - A quick report. Mitigation and Adaptation Strategies for Global Change 16. Dordrecht. DOI: 10.1007/s11027-011-9297-7

Münchner Rückversicherungs-Gesellschaft. Press Release (1.4.2012). München, 2012.

Nukiwa, T. 2012: An overview of respiratory medicine during the Tsunami Disaster at Tohoku, Japan, on March 11, 2011. Respiratory Investigation 50. Amsterdam. DOI: 10.1016/j.resinv.2012.08.004

Richmond, B., Szczuciñski, W., Chagué-Goff, C., Gotoe, K., Sugawaraf, D., Witterg, R., Tappinh, D. R., Jaffe, B., Fujinoi, S., Nishimuraj, Y., Goffc, J. 2012: Erosion, deposition and landscape change on the Sendai coastal plain, Japan, resulting from the March 11, 2011 Tohoku-oki tsunami. Sedimentary Geology 282. New York. DOI: 10.1016/j.sedgeo.2012.08.005

Schmid, M. 2006: The role of science in the management of natural hazards and major risks. PLANAT Series $1 / 2006$. Lausanne.

Svirčev, Z., Krstić, S., Važić, T. 2014: The phylosophy and applicability of ecoremediations for the protection of water ecosystems. Acta geographica Slovenica 54-1 (in press). Ljubljana. DOI: 10.3986/AGS54306

Tošić, R., Dragićević, S., Zorn, M., Lovrić, N. 2014: Landslide susceptibility zonation: A case study from Banja Luka Municipality (Bosnia and Herzegovina). Acta geographica Slovenica 54-1 (in press). Ljubljana. DOI: 10.3986/AGS54307

Tsunami preparedness in Japan. Internet: http://factsanddetails.com/japan.php?itemid=2227\&catid=26\&subcatid $=160(6.6 .2013)$

Zorn, M., Komac, B. 2011: Damage caused by natural disasters in Slovenia and globally between 1995 and 2010. Acta geographica Slovenica 51-1. Ljubljana. DOI: 10.3986/AGS51101 